\title{
Stroke in critical COVID-19 patients: a cautionary tale from the frontlines
}

Anant Jain ${ }^{1}$, Firas Jafri ${ }^{1}$, Ravi Manglani ${ }^{2}$, Fawaz Al-Mufti ${ }^{3}$, Wilbert S. Aronow ${ }^{4}$, Dipak Chandy ${ }^{2}$

${ }^{1}$ Department of Medicine, Westchester Medical Center, Valhalla, NY, USA

${ }^{2}$ Division of Pulmonary, Critical Care and Sleep Medicine, Westchester Medical Center, Valhalla, NY, USA

${ }^{3}$ Department of Neurology, Westchester Medical Center, Valhalla, NY, USA

${ }^{4}$ Department of Cardiology, Westchester Medical Center and New York Medical

College, Valhalla, NY, USA

Submitted: 27 August 2020

Accepted: 30 August 2020

Arch Med Sci Atheroscler Dis 2020; 5: e263-e270

DOI: https://doi.org/10.5114/amsad.2020.102423

Copyright (c) 2020 Termedia \& Banach

\section{Abstract}

Introduction: Although Coronavirus Disease 2019 (COVID-19) is primarily a disease of the respiratory system in its transmission and clinical manifestations, physicians have also reported a tropism toward the nervous system. Methods: Neurological symptoms can occur as one of many systemic manifestations of a critical form of the disease or in isolation as the predominant presenting complaint.

Results: We report a series of 6 patients who suffered significant cerebrovascular accidents while being treated for critical COVID-19 in the intensive care units of a quaternary care hospital in New York's Hudson valley.

Conclusions: This series demonstrates how a relatively rare but catastrophic neurological complication can occur in patients with COVID-19 while they are being managed for their more common problems such as respiratory and renal failure.

Key words: COVID-19, SARS-CoV-2, coronavirus, stroke, cerebrovascular accident.

Coronavirus disease 2019 (COVID-19) is predominantly an acute respiratory disease caused by a single stranded RNA virus known as severe acute respiratory syndrome coronavirus 2 (SARS-CoV-2), which is believed to have originated in Wuhan, China [1]. The virus possesses a spike protein that binds to angiotensin-converting enzyme (ACE2) receptors, primarily expressed on respiratory epithelium, facilitating entry into the host cell [2]. Susceptibility of organ systems to this virus may depend on the extent of expression of ACE2 receptors on cell surfaces. These receptors are expressed on endothelial cells, pericytes, macrophages, glial cells, and cardiac myocytes [2-4]. Viral entry into these cells can lead to diverse manifestations, such as acute respiratory distress syndrome (ARDS), acute kidney injury (AKI), liver injury, cardiac injury, and neurologic complications [3, 5-7].

Neurological symptoms of COVID-19 include headache, confusion, hypogeusia, hyposmia, myalgias, and delirium, while neurological complications include acute ischaemic stroke, encephalopathy, and Guillain-Barre syndrome [3, 6, 8-10]. Autopsy data have revealed cerebral oedema and

\author{
Corresponding author: \\ Wilbert S. Aronow \\ MD, FACC, FAHA, FCCP \\ Department \\ of Cardiology \\ Westchester Medical \\ Center \\ New York Medical College \\ Macy Pavilion \\ Room 141 \\ Valhalla NY 10595, USA \\ Phone: (914)-493-5311 \\ Fax: (914)-235-6274 \\ E-mail:wsaronow@aol.com
}


partial neuronal degeneration in some of these patients [9].

Stroke and coronavirus infections. There have been several proposed mechanisms of neurological involvement after infection with coronavirus es [11]. While early evidence suggests increased risk of acute ischaemic strokes in patients with COVID-19, the exact pathophysiology remains unknown. Some proposed mechanisms are as follows:

1. Endothelial cell dysfunction - The virus may initially invade endothelial cells through ACE2 receptors [12]. The presence of viral elements within endothelial cells, and an accumulation of inflammatory cells, with evidence of inflammatory cell death has been demonstrated in COVID-19 patients [13]. The inflammation of endothelial cells may cause cellular dysfunction, leading to either disruption of stable atherosclerotic plaque or circulatory changes in vascular beds, through a thrombogenic microvascular environment, manifesting as stroke, pulmonary embolism, or myocardial infarction.

2. Inflammation - Critical SARS-Cov-2 infection is almost always accompanied by a significant pro-inflammatory response, which may activate the coagulation cascade through various pathways, leading to a profound prothrombotic state. Patients with other viral infections such as human immunodeficiency virus (HIV), herpes simplex virus, Epstein-Barr virus, and cytomegalovirus have been reported to have decreased activity of protein $\mathrm{C}$ and protein $\mathrm{S}$, and reduced thrombin formation and platelet activation [14-16]. It is possible that this prothrombotic state may lead to disseminated fibrin deposits in the microvasculature similarly to what is seen in disseminated intravascular coagulation (DIC). It is likely that the elevated D-dimer levels often seen in these patients is due to this overactive coagulation state.

3. Complement cascade - SARS-Cov-2 infection has also been linked to activation of both alternative and lectin-based complement cascades. These complement complexes can deposit on endothelial cells leading to cellular damage and initiate a thrombotic microangiopathy [17].

4. Cytokine release syndrome (CRS) - Some patients with critical COVID-19 have been noted to have a profound release of cytokines also known as "cytokine storm". The phenomenon involves an unimpeded release of cytokines such as interleukin (IL)-6, IL-1, IL-2, and IL-7, granulocyte colony stimulating factor, and tumour necrosis factor, to the detriment of the host. High serum IL-6 levels are commonly seen in CRS and have been found to be a clinical predictor of mortality in COVID-19 [7].
5. Vasculitis - another aetiology of strokes associated with viral illnesses is vasculitis, which can be seen in infections with HIV, hepatitis C virus, and herpes zoster [18-20]. Vasculitis has also been seen on autopsy in patients with stroke in SARS-Cov-1 patients [21].

6. The presence of antiphospholipid antibodies and lupus antibodies have also been described in patients with COVID-19, although their clinical significance remains unknown [22]. These antibodies have been associated with a number of viral infections, and although they may pose an increased thrombotic risk, anticoagulation is usually not warranted unless thrombotic sequelae are apparent [23].

Case reports. Details of the 6 patients who developed strokes while being treated for critical COVID-19 are described below. Their pertinent clinical characteristics including modified Rankin Scale (mRS) scores are summarised in Table I. Their CT head findings are displayed in Figure 1.

Patient I. A 41-year-old pregnant female at 22 weeks of gestation presented to our hospital with complaints of fever and cough for 1 week and tested positive for the SARS-CoV-2. She suffered intra-uterine foetal demise and subsequently developed worsening respiratory failure, requiring invasive mechanical ventilation on hospital day 4 . The patient demonstrated significantly increased inflammatory markers suggestive of CRS, with progression to multi-organ failure, including coagulopathy and acute kidney injury requiring renal replacement therapy (RRT). She was treated with hydroxychloroquine, azithromycin, methylprednisolone, tocilizumab, and convalescent plasma. Following physiological improvement and weaning of sedation by hospital day 11 , she was noted to have neurological deficits. CT Head revealed a moderately sized acute/subacute right middle cerebral artery territory infarct and a small cortical left parietal acute/subacute infarct.

Patient II. A 67-year-old male with no significant past medical history presented with fever, chills, cough and worsening dyspnoea for 10 days and tested positive for SARS-CoV-2. He progressed to severe respiratory failure requiring mechanical ventilation, and multi-organ failure caused by what appeared to be CRS. Organ failure included renal failure requiring RRT, coagulopathy, and markedly deranged liver function tests. He received treatment with hydroxychloroquine, azithromycin, methylprednisolone, and tocilizumab. The patient subsequently showed signs of recovery and passed conventional spontaneous breathing trials but was unable to demonstrate a normal mental status. CT head on hospital day 20 showed bilateral ischaemic cerebral hemispheres and left inferior cerebellar infarcts super- 
Table I. Clinical summary of six patients who developed bilateral strokes while being treated for COVID-19

\begin{tabular}{|c|c|c|c|c|c|c|}
\hline Characteristics & Patient I & Patient II & Patient III & Patient IV & Patient V & Patient VI \\
\hline Age & 41 & 67 & 71 & 67 & 52 & 65 \\
\hline Gender & $\mathrm{F}$ & M & $\mathrm{F}$ & $\mathrm{F}$ & M & M \\
\hline BMI & 24.4 & 27.6 & 50.0 & 25.7 & 43.2 & 28.4 \\
\hline $\begin{array}{l}\text { Premorbid } \\
\text { mRS }\end{array}$ & 0 & 0 & 0 & 0 & 0 & 0 \\
\hline $\begin{array}{l}\text { Pre-existing } \\
\text { risk factors for } \\
\text { stroke }\end{array}$ & None & None & $\begin{array}{l}\text { Morbid } \\
\text { obesity }\end{array}$ & $\begin{array}{c}\text { Hypertension } \\
\text { Diabetes } \\
\text { mellitus }\end{array}$ & $\begin{array}{c}\text { Diabetes } \\
\text { mellitus } \\
\text { Hyperlipidae- } \\
\text { mia } \\
\text { Atrial } \\
\text { fibrillation } \\
\text { Morbid } \\
\text { obesity } \\
\text { CAD } \\
\text { PVD }\end{array}$ & $\begin{array}{l}\text { Hyperlipidae- } \\
\text { mia }\end{array}$ \\
\hline $\begin{array}{l}\text { Treatment for } \\
\text { COVID-19 }\end{array}$ & $\begin{array}{l}\text { Hydroxychlo- } \\
\text { roquine } \\
\text { Azithromycin } \\
\text { Methylpred- } \\
\text { nisolone } \\
\text { Tocilizumab } \\
\text { Convalescent } \\
\text { plasma }\end{array}$ & $\begin{array}{l}\text { Hydroxychlo- } \\
\text { roquine } \\
\text { Azithromycin } \\
\text { Methylpred- } \\
\text { nisolone } \\
\text { Tocilizumab }\end{array}$ & $\begin{array}{l}\text { Hydroxychlo- } \\
\text { roquine } \\
\text { Azithromycin } \\
\text { Methylpred- } \\
\text { nisolone }\end{array}$ & $\begin{array}{l}\text { Hydroxychlo- } \\
\text { roquine } \\
\text { Azithromycin } \\
\text { Methylpred- } \\
\text { nisolone } \\
\text { IV heparin }\end{array}$ & $\begin{array}{l}\text { Hydroxychlo- } \\
\text { roquine } \\
\text { Tocilizumab } \\
\text { Convalescent } \\
\text { plasma } \\
\text { IV heparin }\end{array}$ & $\begin{array}{l}\text { Hydroxychlo- } \\
\text { roquine } \\
\text { Azithromycin } \\
\text { Methylpred- } \\
\text { nisolone } \\
\text { Tocilizumab } \\
\text { Convalescent } \\
\text { plasma }\end{array}$ \\
\hline $\begin{array}{l}\text { Met ISTH } \\
\text { criteria for } \\
\text { overt DIC }\end{array}$ & Yes & Yes & Yes & Yes & Yes & Yes \\
\hline $\begin{array}{l}\text { IL-6 levels } \\
{[\mathrm{pg} / \mathrm{ml}]}\end{array}$ & $>400$ & $>400$ & 17 & 19.91 & 107 & 400 \\
\hline $\begin{array}{l}\text { Hypercoagula- } \\
\text { bility workup* }\end{array}$ & Low C4 level & Low AT & Normal & $\begin{array}{c}\text { Elevated Lip A } \\
\text { Low AT } \\
\text { Low protein S }\end{array}$ & $\begin{array}{l}\text { Not per- } \\
\text { formed }\end{array}$ & Normal \\
\hline Head CT & $\begin{array}{l}\text { Small-moder- } \\
\text { ate right fron- } \\
\text { tal lobe infarct } \\
\text { and a small } \\
\text { left parietal } \\
\text { infarct }\end{array}$ & $\begin{array}{l}\text { Infarcts in } \\
\text { right frontal, } \\
\text { parietal, and } \\
\text { occipital } \\
\text { lobes. Small } \\
\text { infarcts within } \\
\text { left frontopa- } \\
\text { rietal and left } \\
\text { paramedian } \\
\text { parieto-occipi- } \\
\text { tal region and } \\
\text { the left inferi- } \\
\text { or cerebellum }\end{array}$ & $\begin{array}{l}\text { Infarcts in the } \\
\text { left temporal } \\
\text { and occip- } \\
\text { ital lobes. } \\
\text { Additional } \\
\text { infarcts in the } \\
\text { left splenium } \\
\text { of the corpus } \\
\text { callosum to } \\
\text { pericallosal } \\
\text { region along } \\
\text { with possible } \\
\text { petechial hae- } \\
\text { morrhage }\end{array}$ & $\begin{array}{l}\text { Multiple in- } \\
\text { farcts bilater- } \\
\text { ally in cerebral } \\
\text { hemispheres } \\
\text { involving the } \\
\text { paramedian } \\
\text { frontal lobes, } \\
\text { occipital } \\
\text { lobes, and left } \\
\text { parietal lobe. } \\
\text { Additional in- } \\
\text { farcts in both } \\
\text { cerebellar } \\
\text { hemispheres }\end{array}$ & $\begin{array}{l}\text { Diffuse bilat- } \\
\text { eral cerebral } \\
\text { infarcts with } \\
\text { haemorrhagic } \\
\text { conversion, in- } \\
\text { traventricular } \\
\text { extension of } \\
\text { haemorrhage, } \\
\text { cerebellar } \\
\text { herniation, } \\
\text { and venous } \\
\text { thrombosis }\end{array}$ & $\begin{array}{c}\text { Acute- } \\
\text { subacute } \\
\text { haemorrhagic } \\
\text { infarction in } \\
\text { left temporal } \\
\text { and occipital } \\
\text { lobes }\end{array}$ \\
\hline $\begin{array}{l}\mathrm{mRS} \text { at } \\
\text { hospital } \\
\text { discharge }\end{array}$ & 4 & 5 & 5 & 6 & 6 & 6 \\
\hline
\end{tabular}

${ }^{*}$ Hypercoagulability workup included lipoprotein A, homocysteine, protein C, protein S, lupus anticoagulant, anticardiolipin antibody (IgM and $\lg G)$, antiB2GP1 antibody (Ig $M$ and $\lg G)$, and complement $(C 3, C 4)$ levels.

imposed with haemorrhage in the right frontoparietal region.

Patient III. A 71-year-old female who tested positive for SARS-CoV-2 in the community 4 days prior to admission, presented with worsening dyspnoea requiring mechanical ventilation. Her treatment regimen included hydroxychloroquine, azithromycin, and methylprednisolone. Hospital course was complicated by septic shock secondary to methicillin-sensitive staphylococcus aureus pneumonia, which responded to treatment with cefazolin. The patient began tolerating spontaneous breathing trials but poor mental status despite remained poor off sedation. CT head on hos- 

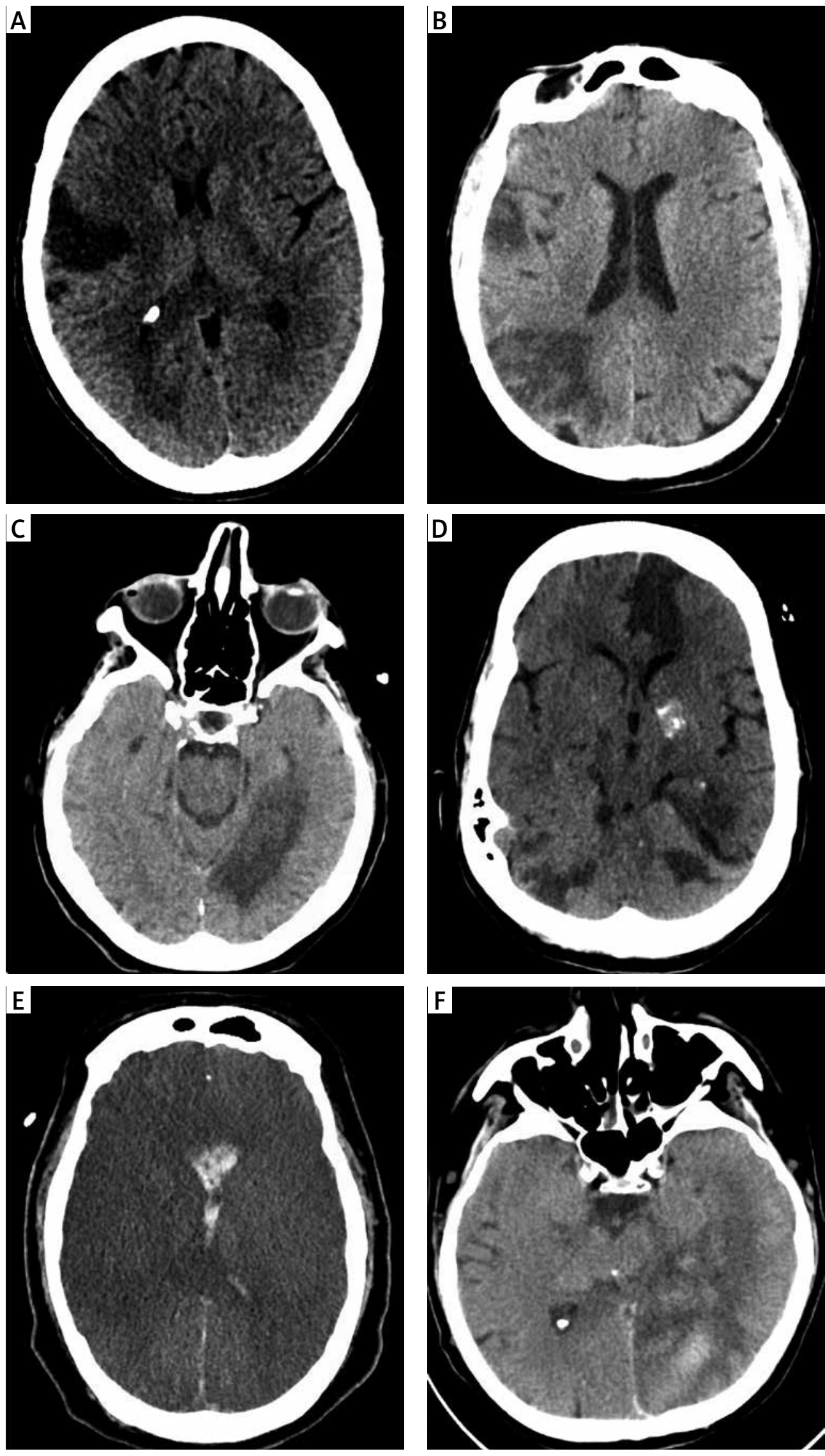

Figure 1. Head CT images of patients (A - patient I, B - patient II, C - patient III, D - patient IV, E - patient V $\mathrm{F}$ - patient $\mathrm{VI}$ ) 
pital day 19 revealed left occipital and temporal infarcts, while CT angiography revealed an acute occlusion of the left posterior cerebellar artery.

Patient IV. A 67-year-old female with a history of hypertension and diabetes mellitus presented with fever and dyspnoea, after having tested positive for SARS-CoV-2 and went on to require mechanical ventilation. She was treated with hydroxychloroquine, azithromycin, and methylprednisolone. On hospital day 4, she was started on a heparin drip due to a sudden spike in the D-dimer level. On hospital day 5, when taken off sedation, her neurological status was noted to be severely compromised. Head CT revealed bilateral cerebral and cerebellar strokes. Anticoagulation was continued but had to be held when subsequent CT scans revealed haemorrhagic conversion of the infarcts.

Patient V. A 52-year-old male with multiple comorbidities, including diabetes mellitus, hyperlipidaemia, morbid obesity, coronary artery disease (CAD), peripheral vascular disease (PVD), atrial fibrillation (A-fib), and chronic obstructive pulmonary disease presented with fever, cough, and dyspnoea and tested positive for SARS-CoV-2. He was treated with hydroxychloroquine, tocilizumab, and convalescent plasma. Due to his history of A-fib, he was started on a heparin drip on hospital day 3 . He rapidly progressed to respiratory failure requiring mechanical ventilation, septic shock requiring vasopressor support, and AKI requiring RRT. On hospital day 16, he was found to have dilated, non-reactive pupils and an absent cough reflex. CT head revealed massive ischaemic and haemorrhagic strokes with cerebellar herniation.

Patient VI. A 65-year-old male with history of hyperlipidaemia presented with a chief complaint of dyspnoea and tested positive for SARS-CoV-2. Chest $\mathrm{X}$-ray revealed bilateral opacities, and he was intubated for worsening respiratory failure. He was treated with azithromycin, hydroxychloroquine, methylprednisolone, tocilizumab, and convalescent plasma. Due to rising D-dimer levels, he was anticoagulated with enoxaparin on hospital day 7. ICU course was complicated by septic shock, thrombocytopaenia, and AKI requiring RRT, and enoxaparin was changed to IV heparin. On day 27 , the patient was minimally responsive off sedation. Head CT revealed haemorrhagic strokes in the left occipital and temporal lobes.

Treatment and outcomes. After the diagnoses of stroke was made in these patients, aspirin and statins were started, and anticoagulation was started or continued whenever possible. Patient I was successfully extubated and discharged to a rehabilitation facility with some neurological deficits. Patients II and III were discharged to long-term care facilities on mechanical ventilation and in significantly neurologically compromised states. Patients IV and VI died of medical complications, while Patient $\mathrm{V}$ progressed to brain death.

Discussion. On the day of or on the 5 days preceding their strokes, all our patients met International Society of Thrombosis and Haemostasis (ISTH) criteria for overt DIC (Figure 2). However, during their hospitalisation, none of these patients demonstrated any clinical evidence of significant bleeding, as would typically have been expected in acute decompensated DIC. Therefore, this suggests that this is more of a DIC-like state or chronic compensated DIC with thrombosis as the major clinical finding [24]. The hypercoagulable workup performed on these patients revealed that two of them had low antithrombin (AT) levels, while no patient tested positive for antiphospholipid antibodies. One patient had low complement (C4) levels suggesting an activation of the complement cascade. All patients had elevated IL- 6 and C-reactive protein (CRP) levels and other clinical features suggestive of CRS (Figure 3). Patients demonstrated a heterogenous distribution of age and $\mathrm{BMI}$ and had variable pre-existing risk factors for stroke.

In patients with ARDS, sedation and analgesia are almost always needed to control agitation, reduce ventilator asynchrony, and decrease oxygen consumption $[25,26]$. Neuromuscular blockade is occasionally needed to achieve these goals. Daily interruption of these continuous infusions, which has been shown to reduce duration of mechanical ventilation, is part of routine practice in intensive care units [27]. Patients with COVID-19 ARDS who are mechanically ventilated should ideally be treated no differently. Unfortunately, the concern about limiting exposure of healthcare workers to these patients often leads to over-sedation and inadequate sedation holidays. Patients are also probably being examined less thoroughly and less frequently. All these factors can lead to a delay in the diagnosis of an acute cerebrovascular accident and impact their receiving lifesaving or morbidity-sparing treatments. Our case series underscores the importance of being vigilant about cerebrovascular accidents while caring for these patients, and of maintaining sedation at as low a level as possible. Having a lower threshold for obtaining cerebral imaging may also be advisable.

While treatment guidelines for patients with COVID-19 and strokes are emerging, it is unclear if any intervention can prevent these outcomes [28]. Although anticoagulation is being used prophylactically at many centres to prevent the thrombotic complications related to COVID-19, its benefit in stroke prevention remains to be seen. Three of our patients were on anticoagulation when their strokes were detected, and in two of these patients the anticoagulation may have contributed to the haemorrhagic conversion of their strokes. 
A

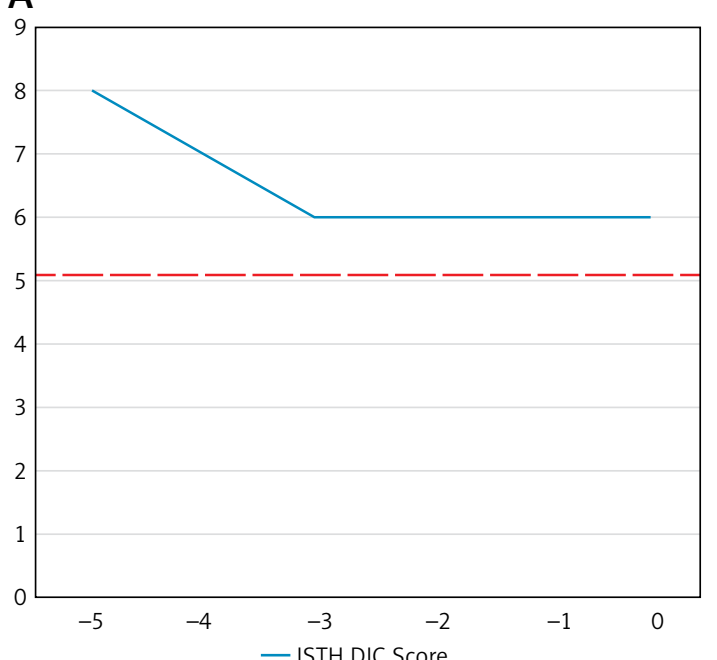

C

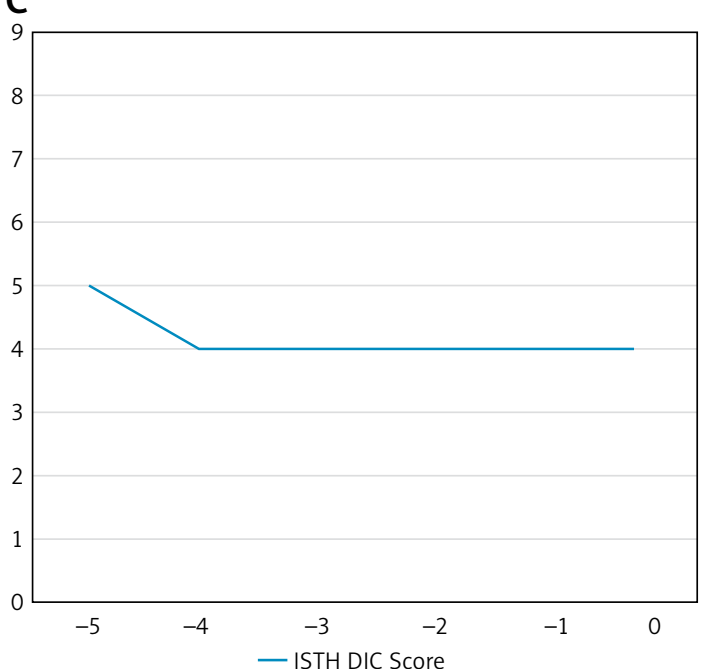

E

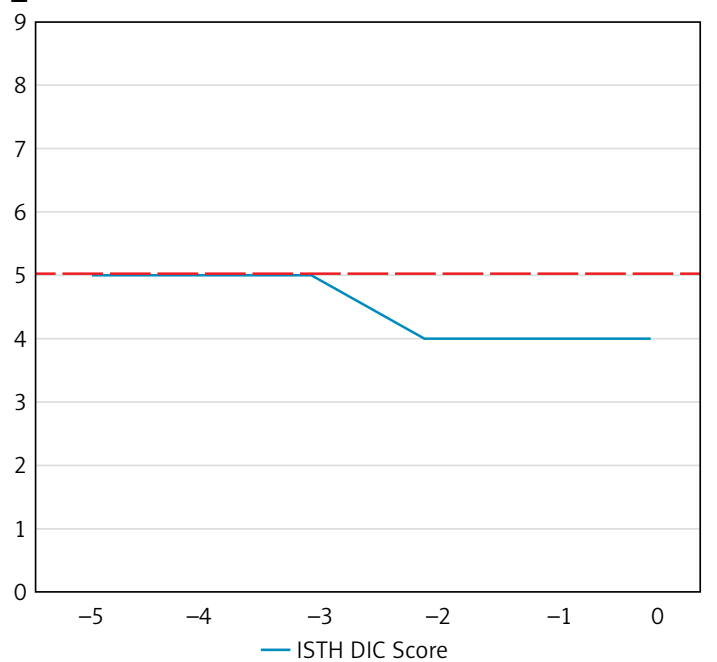

B

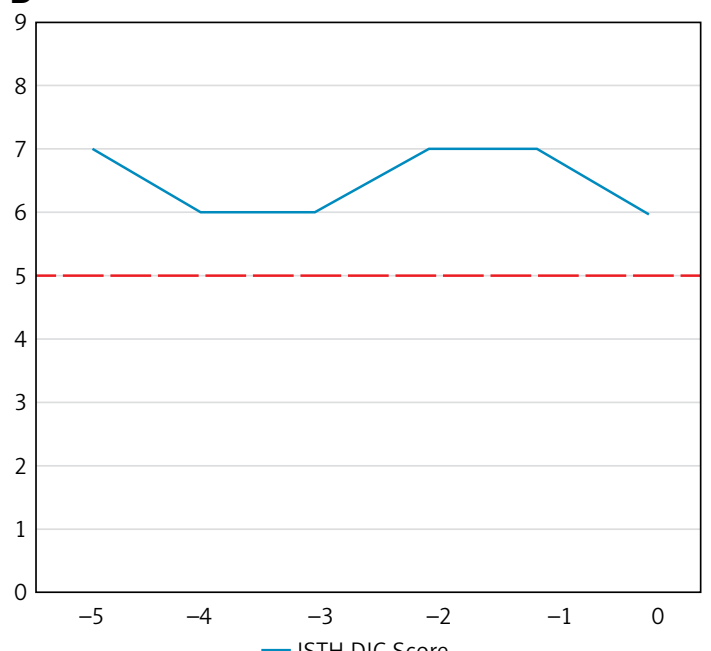

D

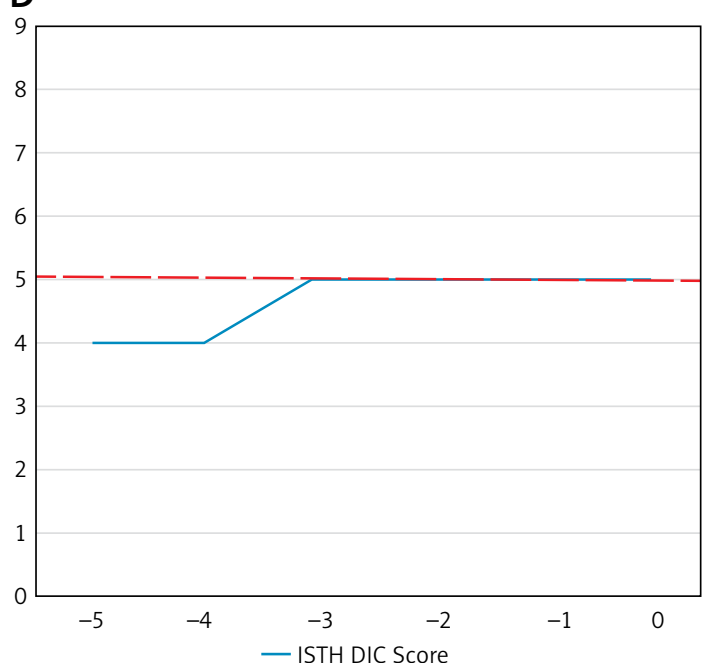

F

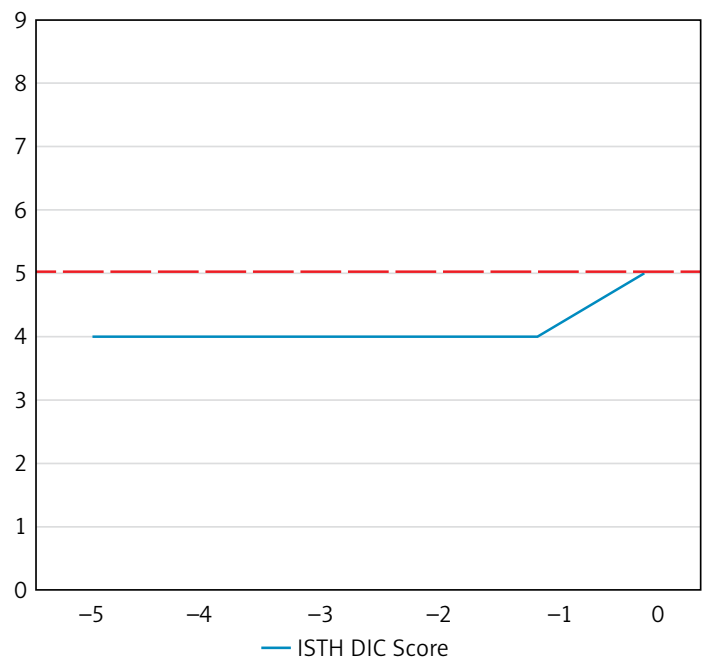

Figure 2. Trend of ISTH criteria for DIC on the days prior to the detection of stroke (designated as day 0) (Scoring system incorporates platelet count, D-dimer, PT, and fibrinogen levels; a score $\geq 5$ is suggestive of overt DIC) (A - patient I, B - patient II, C - patient III, D - patient IV, E - patient V, F - patient VI) 
A

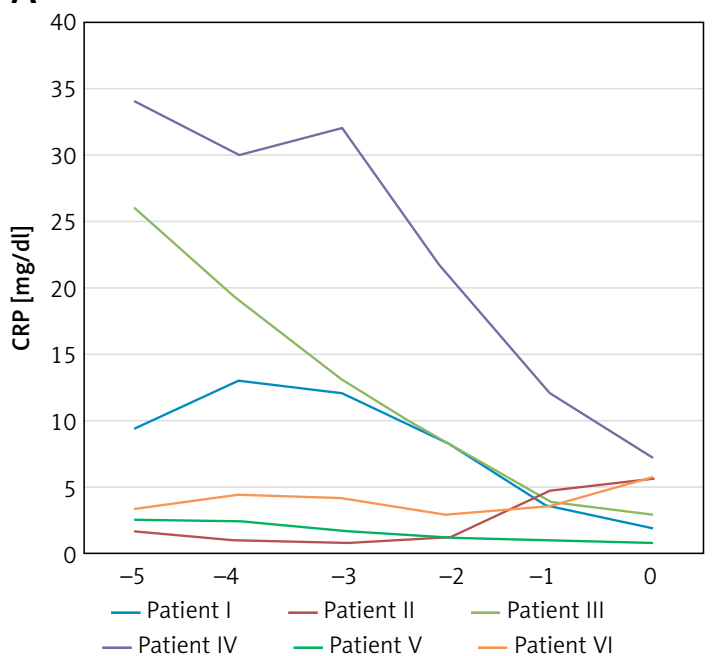

C

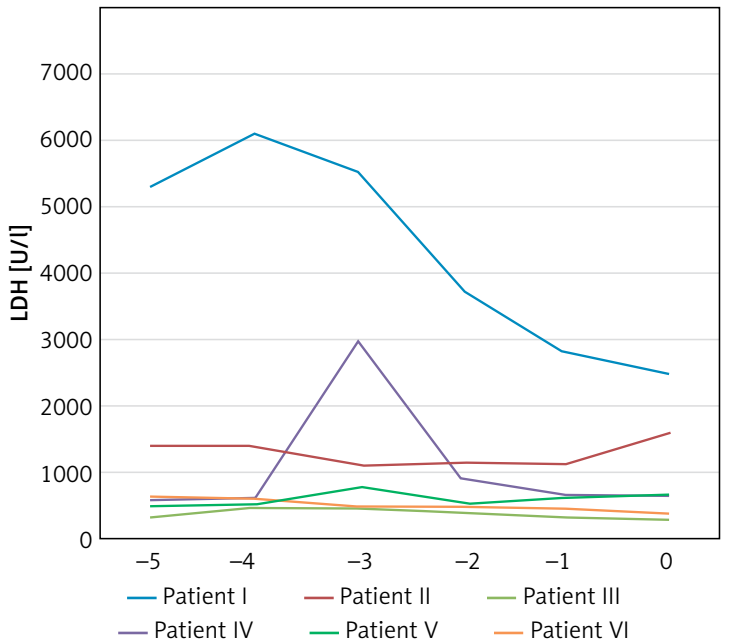

While anti-platelet therapy is the gold standard for the secondary prevention of non-cardioembolic strokes, their prophylactic role in COVID-19 patients has yet to be determined.

Our case series does not elucidate a single predominant mechanism for the development of stroke in these patients infected with SARS-CoV-2, but rather points to a multifactorial cause of the cerebrovascular accidents. Certain diagnostic studies such as Doppler examinations to identify deep venous thrombosis, $\mathrm{CT}$ of the chest to identify pulmonary embolism, and echocardiography to identify patent foramen ovale were not performed, in order to limit exposure of healthcare workers to the virus and because it was felt that the results of these studies would not significantly alter the management of these patients. This is a limitation of our case series, but the likelihood that most or all these patients had embolic strokes is extremely low.

In conclusion, SARS-CoV-2 has already infected millions of patients worldwide. While a wide variety of medications and strategies have been at-
B

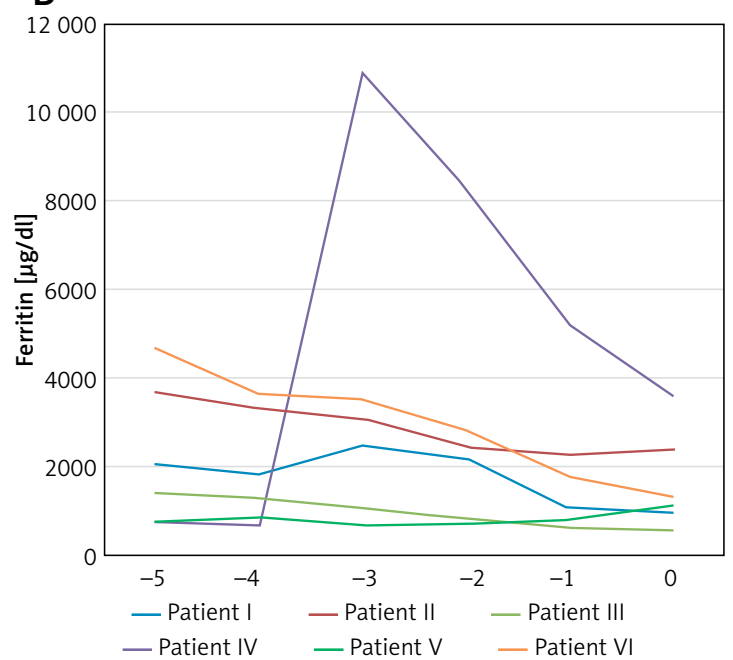

Figure 3. Trend of inflammatory markers on the days prior to the detection of stroke (designated as day 0) (A - CRP levels, B - ferritin levels, $\mathbf{C}$ - LDH levels)

tempted, there is no standard of care that has yet been established for the treatment of COVID-19. Cerebrovascular accidents in these patients are catastrophic complications and are associated with significantly increased mortality and morbidity. Much more research is needed to elucidate the predominant mechanisms of stroke pathogenesis in COVID-19 patients, which will be the first step to instituting prophylactic interventions for these patients. Until such time, healthcare workers should remain extremely vigilant to the possibility of these complications, so that potential treatments do not have to be withheld due to diagnostic delays.

\section{Conflict of interest}

The authors declare no conflict of interest.

\section{References}

1. Wu F, Zhao S, Yu B, et al. A new coronavirus associated with human respiratory disease in China. Nature 2020; 579: 265-9. 
2. Lu R, Zhao X, Li J, et al. Genomic characterisation and epidemiology of 2019 novel coronavirus: implications for virus origins and receptor binding. Lancet 2020; 395: 565-74.

3. Mankad K, Perry MD, Mirsky DM, Rossi A. COVID-19: a primer for neuroradiologists. Neuroradiology 2020; 62: 647-8.

4. Baig AM, Khaleeq A, Ali U, Syeda $H$. Evidence of the COVID-19 virus targeting the cns: tissue distribution, host-virus interaction, and proposed neurotropic mechanisms. ACS Chem Neurosci 2020; 11: 995-8.

5. Ruan Q, Yang K, Wang W, Jiang L, Song J. Clinical predictors of mortality due to COVID-19 based on an analysis of data of 150 patients from Wuhan, China. Intensive Care Med 2020; 46: 846-8.

6. Li YC, Bai WZ, Hashikawa T. The neuroinvasive potential of SARS-CoV2 may play a role in the respiratory failure of COVID-19 patients. J Med Virol 2020; 92: 552-5.

7. Puelles VG, Lütgehetmann M, Lindenmeyer MT, et al. Multiorgan and renal tropism of SARS-CoV-2. N Engl J Med 2020; 383: 590-2.

8. Wang HY, Li XL, Yan ZR, Sun XP, Han J, Zhang BW. Potential neurological symptoms of COVID-19. Ther Adv Neurol Disord 2020; 13: 1756286420917830.

9. Mao L, Jin H, Wang M, et al. Neurologic manifestations of hospitalized patients with coronavirus disease 2019 in Wuhan, China. JAMA Neurol 2020; 77: 683-90.

10. Toscano G, Palmerini F, Ravaglia S, et al. Guillain-Barré syndrome associated with SARS-CoV-2. N Engl J Med 2020. doi:10.1056/NEJMc2009191.

11. Wu Y, Xu X, Chen Z, et al. Nervous system involvement after infection with COVID-19 and other coronaviruses. Brain Behav Immun 2020; 87: 18-22.

12. Chen L, Li X, Chen M, Feng Y, Xiong C. The ACE2 expression in human heart indicates new potential mechanism of heart injury among patients infected with SARS-CoV-2. Cardiovasc Res 2020; 116: 1097-100.

13. Varga Z, Flammer AJ, Steiger $P$, et al. Endothelial cell infection and endotheliitis in COVID-19. Lancet 2020; 395: 1417-8.

14. Shen YM, Frenkel EP. Thrombosis and a hypercoagulable state in HIV-infected patients. Clin Appl Thromb Hemost 2004; 10: 277-80.

15. Key NS, Vercellotti GM, Winkelmann JC, et al. Infection of vascular endothelial cells with herpes simplex virus enhances tissue factor activity and reduces thrombomodulin expression. Proc Natl Acad Sci USA 1990; 87: 7095-9.

16. Rahbar A, Söderberg-Nauclér C. Human cytomegalovirus infection of endothelial cells triggers platelet adhesion and aggregation. J Virol 2005; 79: 2211-20.

17. Magro C, Mulvey JJ, Berlin D, et al. Complement associated microvascular injury and thrombosis in the pathogenesis of severe COVID-19 infection: a report of five cases. Transl Res 2020; 220: 1-13.

18. Doyle PW, Gibson G, Dolman CL. Herpes zoster ophthalmicus with contralateral hemiplegia: identification of cause. Ann Neurol 1983; 14: 84-5.

19. Khella SL, Souayah N. Hepatitis C. A review of its neurologic complications. Neurologist 2002; 8: 101-6.

20. Nogueras C, Sala M, Sasal M, et al. Recurrent stroke as a manifestation of primary angiitis of the central nervous system in a patient infected with human immunodeficiency virus. Arch Neurol 2002; 59: 468-73.

21. Ding $Y$, Wang $H$, Shen $H$, et al. The clinical pathology of severe acute respiratory syndrome (SARS): a report from China. J Pathol 2003; 200: 282-9.
22. Zhang Y, Xiao M, Zhang S, et al. Coagulopathy and antiphospholipid antibodies in patients with COVID-19. N Engl J Med 2020; 382: e38.

23. Uthman IW, Gharavi AE. Viral infections and antiphospholipid antibodies. Semin Arthritis Rheum 2002; 31: 256-63.

24. Klok FA, Kruip MJHA, van der Meer NJM, et al. Incidence of thrombotic complications in critically ill ICU patients with COVID-19. Thromb Res 2020; 191: 145-7.

25. Swinamer DL, Phang PT, Jones RL, Grace M, King EG. Effect of routine administration of analgesia on energy expenditure in critically ill patients. Chest 1988; 93 4-10. 4

26. Hansen-Flaschen J. Improving patient tolerance of mechanical ventilation. Challenges ahead. Crit Care Clin 1994; 10: 659-71.

27. Girard TD, Kress JP, Fuchs BD, et al. Efficacy and safety of a paired sedation and ventilator weaning protocol for mechanically ventilated patients in intensive care (Awakening and Breathing Controlled trial): a randomised controlled trial. Lancet 2008; 371: 126-34.

28. Qureshi Al, Abd-Allah F, Alsenani F, et al. Management of acute ischemic stroke in patients with COVID-19 infection: report of an international panel. Int J Stroke 2020; 15: 540-54. 